\title{
Induction of apoptosis in cancer cells by tumor necrosis factor and butyrolactone, an inhibitor of cyclin-dependent kinases
}

J.E. Belizário ${ }^{1,2}$,

S. Sherwood ${ }^{3}$ and W. Beçak ${ }^{1}$
${ }^{1}$ Laboratório de Genética, Instituto Butantan, São Paulo, SP, Brasil 2Departamento de Farmacologia, Instituto de Ciências Biomédicas, Universidade de São Paulo, São Paulo, SP, Brasil

${ }^{3}$ Genentech, Inc., South San Francisco, CA, USA

\section{Correspondence \\ J.E. Belizário \\ Departamento de Farmacologia \\ ICB, USP \\ 05508-900 São Paulo, SP \\ Brasil \\ E-mail: jebeliza@ usp.br}

Research supported by FAPESP (Nos. 93/0327-4 and 96/0860-6) and CNPq (Nos. 400187-93 and 300786/94-8).

Received May 20, 1998 Accepted December 21, 1998

\section{Abstract}

Induction of apoptosis by tumor necrosis factor (TNF) is modulated by changes in the expression and activity of several cell cycle regulatory proteins. We examined the effects of TNF (1-100 ng/ml) and butyrolactone I $(100 \mu \mathrm{M})$, a specific inhibitor of cyclin-dependent kinases (CDK) with high selectivity for CDK-1 and CDK-2, on three different cancer cell lines: WEHI, L929 and HeLa S3. Both compounds blocked cell growth, but only TNF induced the common events of apoptosis, i.e., chromatin condensation and ladder pattern of DNA fragmentation in these cell lines. The TNF-induced apoptosis events were increased in the presence of butyrolactone. In vitro phosphorylation assays for exogenous histone $\mathrm{H} 1$ and endogenous retinoblastoma protein $(\mathrm{pRb})$ in the total cell lysates showed that treatment with both TNF and butyrolactone inhibited the histone H1 kinase (WEHI, L929 and $\mathrm{HeLa}$ ) and pRb kinase (WEHI) activities of CDKs, as compared with the controls. The role of proteases in the TNF and butyrolactoneinduced apoptosis was evaluated by comparing the number and expression of polypeptides in the cell lysates by gel electrophoresis. TNF and butyrolactone treatment caused the disappearance of several cellular protein bands in the region between 40-200 kDa, and the 11090- and $50-\mathrm{kDa}$ proteins were identified as the major substrates, whose degradation was remarkably increased by the treatments. Interestingly, the loss of several cellular protein bands was associated with the marked accumulation of two proteins apparently of 60 and $70 \mathrm{kDa}$, which may be cleavage products of one or more proteins. These findings link the decrease of cyclin-dependent kinase activities to the increase of protease activities within the growth arrest and apoptosis pathways induced by TNF.
Key words

- Apoptosis

- Cell cycle

- Cyclin-dependent kinases

- Cyclin-dependent kinase

chemical inhibitors

- Tumor necrosis factor 


\section{Introduction}

Tumor necrosis factor- $\alpha$ (TNF- $\alpha$ ) is a $17-\mathrm{kDa}$ protein primarily produced by macrophages with a wide range of biological activities (1). TNF exerts cytotoxic or cytostatic effects on a variety of cell types, which may result in cell death by apoptosis (2). Apoptosis is a selective program for cell death controlled by specific genes, which either suppress (bcl-2/CED-9 protein family) or promote it (CED-3/ICE protein family) $(3,4)$. The molecular and morphological events triggered by these regulatory proteins lead to the internucleosomal fragmentation of DNA, degeneration of nuclear and cytoplasmic structures and formation of membrane-bound apoptotic bodies, which are engulfed by neighboring cells or tissue macrophages $(5,6)$. Recently, a network of genes, including various cell cycle genes, protooncogenes, tumor suppressor genes and cell death genes, was shown to play major roles on the regulation of cell growth, differentiation and apoptosis as well as in tumor progression (7-9). Two interrelated cellular processes, the cell cycle and cell death, are involved simultaneously during the cellular response to TNF, with some cell types showing that growth arrest was accompanied by apoptosis. The growth inhibitory effects of TNF in normal and cancer cells have been associated with a $\mathrm{G}_{1}$ phase arrest (10) and a decrease in the activity of cyclin-dependent kinases (CDKs) (11), the inhibition of the expression of cyclin A, cyclin B (11-13) and a concomitant increase of the tumor suppressor protein $\mathrm{p} 53$ and the CDK inhibitory protein, p21 (14-16). Furthermore, the expression of both cyclin D3 and c-myc can sensitize cancer cells to TNF-induced apoptosis (17).

Molecular interaction-based screens have revealed molecules derived from microorganisms, plants and animals which inhibit the activity of the cyclin-dependent kinases (CDK-1 to 7) and their regulatory catalytic subunits, cyclins A to $H(18,19)$. Butyrolactone I is a microbial alkaloid isolated from an Aspergillus strain (20) which is a competitive inhibitor of ATP binding to the ATPbinding pocket of the CDKs. Butyrolactone is a highly selective inhibitor of CDK-1 and CDK-2 in vitro and was shown to arrest the normal and cancer cell cycle progression from the $G_{1}$ to the $S$ phase and from the $G_{2}$ to the $\mathrm{M}$ phase (21). Moreover, it suppresses the phosphorylation of $p R b$ at the $\mathrm{G}_{1}-\mathrm{S}$ phase and promotes apoptosis of HL-60 cells at doses of 20-50 $\mu \mathrm{M}$ (22). The present data show that the induction by TNF of both chromatin condensation and DNA fragmentation in the cancer cell lines WEHI, L929 and HeLa S3 is increased in the presence of butyrolactone. These effects were accompanied by the inhibiton of histone $\mathrm{H} 1$ and $\mathrm{pRb}$ kinase activities as well as by the proteolysis of several cellular proteins in the apoptotic cells compared with untreated control cells.

\section{Material and Methods}

\section{Cell culture and drug treatment}

The cell lines WEHI, methylcholanthreneinduced mouse fibrosarcoma (CRL 1751), L929, mouse fibrosarcoma (CCL 1), and HeLa S3, human cervix carcinoma (CCL 2.2) were obtained from the Americam Type Culture Collection. The cells were maintained in DMEM, $10 \%$ fetal bovine serum, 2 $\mathrm{mM}$ glutamine and antibiotics in a $5 \% \mathrm{CO}_{2}$ incubator. The cells were separated using trypsin/EDTA solution and harvested by centrifugation at $800 \mathrm{~g}$ for $5 \mathrm{~min}$. For the cytotoxic assays, cells were incubated with complete medium with or without TNF (1-100 $\mathrm{ng} / \mathrm{ml}$ ) of human or mouse origin. Recombinant mouse and human TNF were provided by Genentech, Inc. (South San Francisco, CA, USA). At the time indicated, the dead cells and adherent cell populations were harvested by centrifugation, washed with PBS and divided into aliquots for the morpho- 
logical and biochemical assays. The effects of butyrolactone I, a selective inhibitor of CDK-1 and CDK-2 kinase activity (20,21), on cell growth and apoptosis were determined by incubating the cell lines with 100 $\mu \mathrm{M}$ of the drug for $1 \mathrm{~h}$ following the addition of TNF and by further incubation for 1-24 $\mathrm{h}$. Butyrolactone was provided by Dr. Akira Okuyama (Banyu Tsukuba Research Institute and Merck Research Labs, Okubo, Japan).

\section{Detection of normal and apoptotic changes in cancer cell nuclei}

Changes in nuclear volume during the cell growth and chromatin condensation caused by the different treatments were evaluated by fluorescence microscopy after staining with $1 \mu \mathrm{g} / \mathrm{ml}$ of the DNA-binding fluorochrome Hoechst 33242. Apoptotic nuclei were scored on the basis of the condensation state of chromatin and its marginalization at the edges of nuclear membrane (23). A minimum of three fields containing 100 cells per field were counted in three independent experiments.

\section{DNA fragmentation assay}

The assay was carried out as previously reported (23), with modifications. A total amount of $1-2 \times 10^{6}$ cells were suspended in $400 \mu$ of the homogenization buffer $(0.1 \mathrm{M}$ $\mathrm{NaCl}, 10 \mathrm{mM}$ EDTA, $0.3 \mathrm{M}$ Tris-HCl, $\mathrm{pH}$ 8.0, $0.2 \mathrm{M}$ sucrose, and $0.01 \% \mathrm{SDS}$ ) in Eppendorf tubes and incubated for $1 \mathrm{~h}$ in a water bath at $65^{\circ} \mathrm{C}$. Next, $70 \mu \mathrm{l}$ of $8 \mathrm{M}$ potassium acetate was added and the preparation was incubated on ice for $60 \mathrm{~min}$ and centrifuged at $3000 \mathrm{~g}$ for $10 \mathrm{~min}$ at $4^{\circ} \mathrm{C}$. The upper phase was transferred to a new Eppendorf tube and DNA extraction was performed with 1 volume of phenol:chloroform:isoamylalcohol solution $(25: 24: 1)$ and precipitated with 2 volumes of $100 \%$ ethanol overnight at $-70^{\circ} \mathrm{C}$. DNA was quantified by spectrophotometry at $260 / 280 \mathrm{~nm}$. Aliquots of DNA containing 5-10 $\mu \mathrm{g}$ were electrophoresed on $2 \%$ agarose gel with ethidium bromide and DNA bands were photographed by UV transillumination.

\section{$\mathrm{H}$ istone $\mathrm{H} 1$ and $\mathrm{pRb}$ kinase assays}

Culture samples were trypsinized and centrifuged and the pellet obtained was lysed by rapid freezing and thawing and sonication for $20 \mathrm{~s}$ three times. The cell lysates were cleared by centrifugation at $10,000 \mathrm{~g}$ for 30 $\mathrm{min}$. The protein concentration in the supernatants was determined by the Bradford protein assay (BioRad Laboratories, Hercules, CA, USA). The histone H1 kinase reaction (24) was carried out in a total 50- $\mu$ l volume of $50 \mathrm{mM}$ Tris- $\mathrm{HCl}$, $\mathrm{pH} 7.4,10 \mathrm{mM} \mathrm{MgCl}$, $1 \mathrm{mM}$ DTT, and $50 \mu \mathrm{M}$ ATP (reaction buffer), containing $10 \mu \mathrm{g}$ of protein from one sample, and $5 \mu \mathrm{g}$ purified histone $\mathrm{H} 1$ and 5 $\mu \mathrm{Ci}$ of $\left[\gamma^{32} \mathrm{P}\right]$ ATP $(3000 \mathrm{Ci} / \mathrm{mmol}$, Amersham, Buckingham, UK). The changes in the expression and phosphorylation status of cellular proteins were analyzed after SDSPAGE by the method of Laemmli (25). A mixture of protein molecular mass standards (Gibco/BRL, Gaithersburg, MD, USA) was used to determine the apparent molecular masses of proteins. The gels were fixed, stained with $0.1 \%$ Coomassie blue, dried and analyzed by autoradiography.

\section{Western blot analysis}

Protein lysates of cell samples were obtained after homogenization with buffer $\mathrm{A}$ (100 mM Tris, pH 7.5, $150 \mathrm{mM} \mathrm{NaCl,} 1 \%$ Triton X-100, $10 \mu \mathrm{g} / \mathrm{ml}$ aprotinin, $1 \mu \mathrm{g} / \mathrm{ml}$ leupeptin, $10 \mu \mathrm{g} / \mathrm{ml}$ soybean trypsin inhibitor, $2 \mathrm{mM}$ phenyl-methylsulfonyl fluoride, and $5 \mathrm{mM}$ dithiothreitol) and sonication for $20 \mathrm{~s}$ three times. Equal amounts of proteins, estimated by the Bradford protein assay (BioRad), were separated by $10 \%$ SDS/ PAGE and transferred electrophoretically to 
a nitrocellulose membrane. The retinoblastoma monoclonal antibody RB1(1F8) from Zymed (San Franscisco, CA, USA) was used as the first antibody and a horseradish peroxidase-conjugated rabbit anti-mouse antibody was used as second antibody, at appropriate dilutions. Detection of immunoblots was carried out with the ECL Western blotting detection system (Amersham, Arlington Heights, IL, USA).

\section{Results}

\section{Butyrolactone enhances TNF-induced apoptosis in cancer cells}

In previous studies $(10,23)$ we have determined the doses and times necessary for TNF to induce cell cycle perturbations and cell death in the rodent cell lines WEHI and L929 and the human cell line HeLa. In the present study, we examined the relative changes in size and condensation of nuclear chromatin typical of apoptosis in these cell lines after their growth stimulation with fetal calf serum in the absence or presence of butyrolactone, TNF or both compounds, for various times. Butyrolactone as a single agent, at the dose from 20 to $100 \mu \mathrm{M}$, did not induce apoptosis in these three cell lines.

Table 1 - Induction of apoptotic cell death by tumor necrosis factor (TNF) and the combination of TNF plus butyrolactone in mouse and human cell lines.

Cell lines were incubated without or with butyrolactone $(100 \mu \mathrm{M})$ for $1 \mathrm{~h}$ and then with TNF. The concentration of TNF (mouse or human recombinant protein) added and time of incubation were, respectively, $1 \mathrm{ng} / \mathrm{ml}$ and $15 \mathrm{~h}$ for WEHl, $10 \mathrm{ng} / \mathrm{ml}$ and $24 \mathrm{~h}$ for L929, and $100 \mathrm{ng} / \mathrm{ml}$ and $24 \mathrm{~h}$ for HeLa. Apoptotic nuclei were scored on the basis of the condensation state of chromatin and its marginalization at the edges of the nuclear membrane. Data are reported as the mean percent of apoptotic cells \pm standard deviation of the results of three similar experiments.

\begin{tabular}{cccccc}
\hline Cell type & Control & $\begin{array}{c}\text { Butyrolactone } \\
\text { alone }\end{array}$ & $\begin{array}{c}\text { TNF } \\
\text { alone }\end{array}$ & $\begin{array}{c}\text { TNF }+ \\
\text { butyrolactone }\end{array}$ & $\begin{array}{c}\text { Increase } \\
(\%)\end{array}$ \\
\hline $\begin{array}{c}\text { Mouse } \\
\text { WEHI }\end{array}$ & $<2$ & $<2$ & $73.0 \pm 13$ & $87.3 \pm 11$ & 19 \\
$\begin{array}{c}\text { L929 } \\
\text { Human }\end{array}$ & $<1$ & $<1$ & $64.8 \pm 6.6$ & $86.5 \pm 3.6$ & 33 \\
HeLa & $<1$ & $<1$ & $22.5 \pm 3.1$ & $39.6 \pm 2.2$ & 76 \\
\hline
\end{tabular}

The treatment, however, caused a progressive increase in the number of cells with large nuclei (data not shown), which may be related to the cell cycle arrest at the $\mathrm{G}_{2} / \mathrm{M}$ phase induced by the drug (21). Pre-incubation with butyrolactone for $1 \mathrm{~h}$, followed by the addition of TNF and further incubation of WEHI (15 h), L929 (20 h) and HeLa (20 h), caused an increase of 19, 33 and $76 \%$, respectively, of the apoptotic cells, as compared with TNF alone (Table 1). Apoptosis was further confirmed by comparing the integrity of isolated cellular DNA by agarose gel electrophoresis. The results (Figure 1) show that the typical ladder pattern of DNA fragmentation was induced for each cell line incubated with TNF and TNF plus butyrolactone. A higher proportion of fragmented DNA was obtained in cells treated with TNF plus butyrolactone, consistent with the morphological data (Table 1).

\section{Inhibition of histone $\mathrm{H} 1$ kinase and $\mathrm{pRb}$ kinase activities by TNF and butyrolactone}

Inhibition of cellular growth and induction of apoptosis by TNF (10) and butyrolactone (20-22) in various cell types have been associated with the ability of these compounds to reduce the activity of protein kinases that catalyze the phosphorylation of histone $\mathrm{H} 1$ and $\mathrm{pRb}$ proteins. Consistent with the previous reports, we noted that the exposure of the three cell lines to TNF reduced the histone $\mathrm{H} 1$ kinase activities within the cells (Figure 2A). The level of reduction in the histone $\mathrm{H} 1$ kinase activity increased with the combination of the TNF and butyrolactone compared to TNF alone. The reduction was more evident with the cell lines WEHI and L929, but not clear with HeLa. We analyzed the phosphorylation status of $\mathrm{pRb}$ in the WEHI cell line after the different treatments (Figure 2B). The control and butyrolactonetreated cells exhibited the three phosphorylated forms of $\mathrm{pRb}$ whereas the cells exposed to TNF or TNF plus butyrolactone showed 
only the fast migrating form of $\mathrm{pRb}$ (about $105 \mathrm{kDa})$. We also observed in the autoradiographs the presence of a faint band of 68 $\mathrm{kDa}$, which may be a cleavage product from $\mathrm{Rb}$ proteins (26). We also detected this 68$\mathrm{kDa}$ product with the $\mathrm{Rb}$ monoclonal antibody (data not shown).

\section{Differential expression of proteins in the cell lysates from TNF- and butyrolactone-treated cells}

We monitored the relative effects of TNF and butyrolactone on the synthesis and degradation of cellular proteins to detect other molecular targets associated with the inhibition of cell growth and induction of apoptosis in WEHI cells in which the extent of cell death was nearly $90 \%$. The content and molecular size of numerous proteins did not change in the cells exposed to butyrolactone alone as compared to controls (Figure 3 ). The intensity of polypeptide bands in the
Coomassie-stained gels showed that the proteins of approximately 110,90 and $50 \mathrm{kDa}$ were drastically reduced in the cell lysates from the cells treated with TNF. This occurred with the simultaneous appearance of the two proteins of 60 and $70 \mathrm{kDa}$. The effect was increased when we used the combination of TNF and butyrolactone. It is interesting to observe that the protein bands between 110-120 kDa (location of $\mathrm{pRb}$ hyperphosphorylated forms) were $\mathrm{ab}$ sent in the samples from the TNF and the TNF plus butyrolactone cell lysates. The data suggest that the lack of various protein bands in the 40-200 kDa range and the simultaneous appearance of new bands of 60 and $70 \mathrm{kDa}$, as well as of weak bands on the gel, may be the result of proteolysis of cellular proteins and the generation of smaller cleavage products. The data also indicate that the changes may be the result of up or down regulation of gene expression induced by these agents.

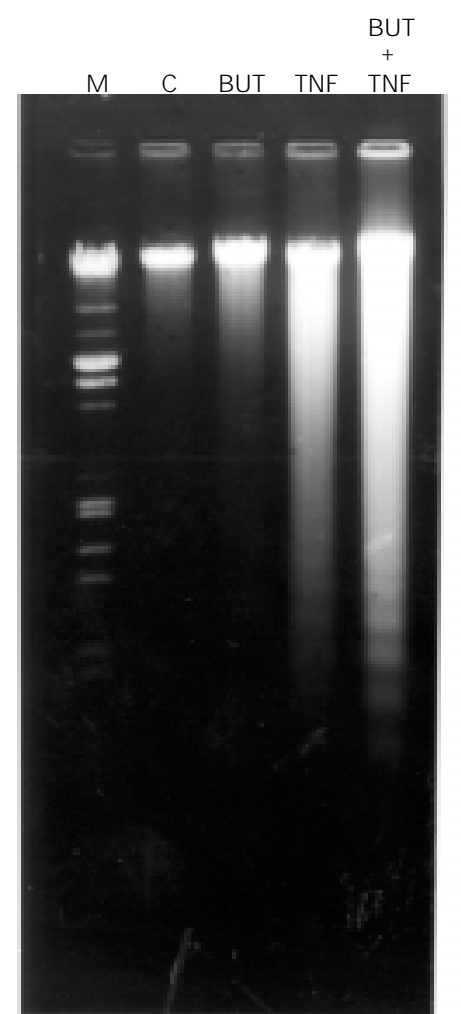

WEHI

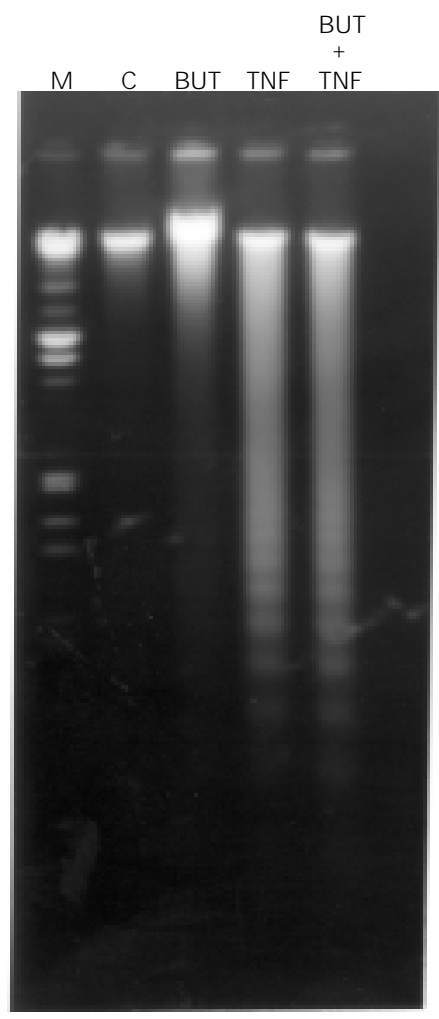

L929

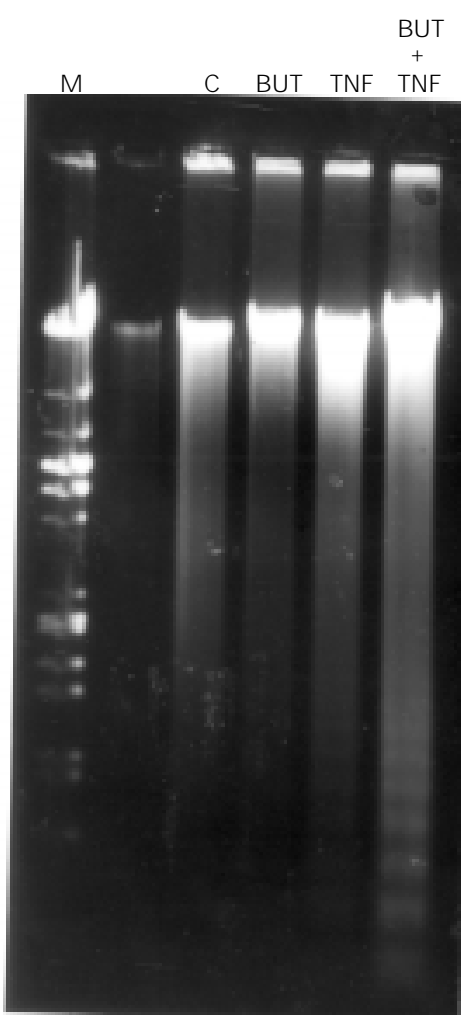

HeLa
Figure 1 - Agarose gel electrophoresis of genomic DNA extracted from WEHI, L929 and HeLa cells incubated in the absence $(\mathrm{C})$ and in the presence of $100 \mu \mathrm{M}$ butyrolactone (BUT), in the presence of tumor necrosis factor (TNF) at 1, 5 and 100 $\mathrm{ng} / \mathrm{ml}$, respectively, or both butyrolactone and TNF for $15 \mathrm{~h}$ (WEHI cells) or $24 \mathrm{~h}$ (L929 and HeLa cells). The relative mobility of the oligonucleosomal fragments from DNA samples reflects interger multiples of a 180-bp unit (apoptosis ladder pattern) with respect to the DNA standard (M). 

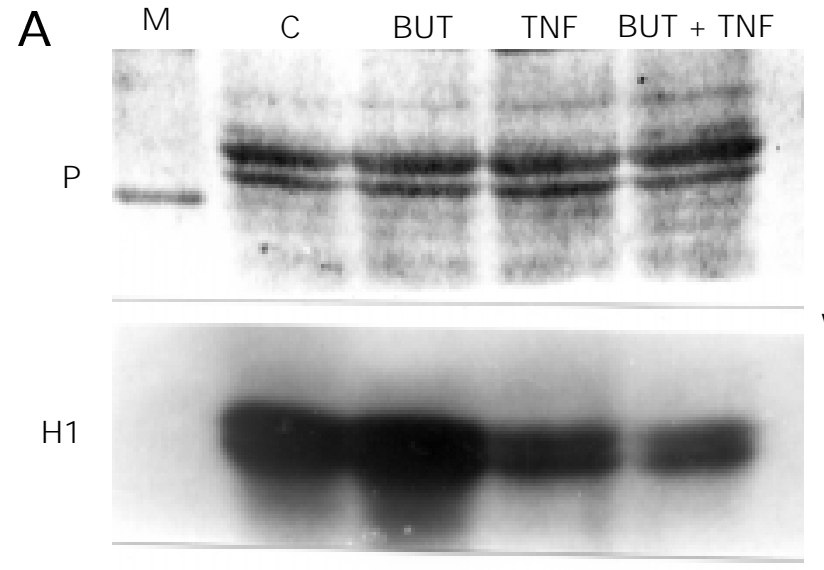

WEHI

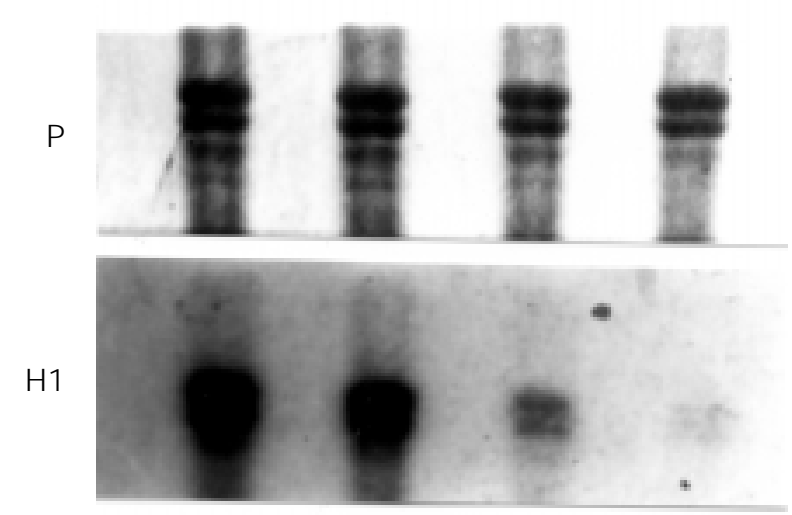

L929
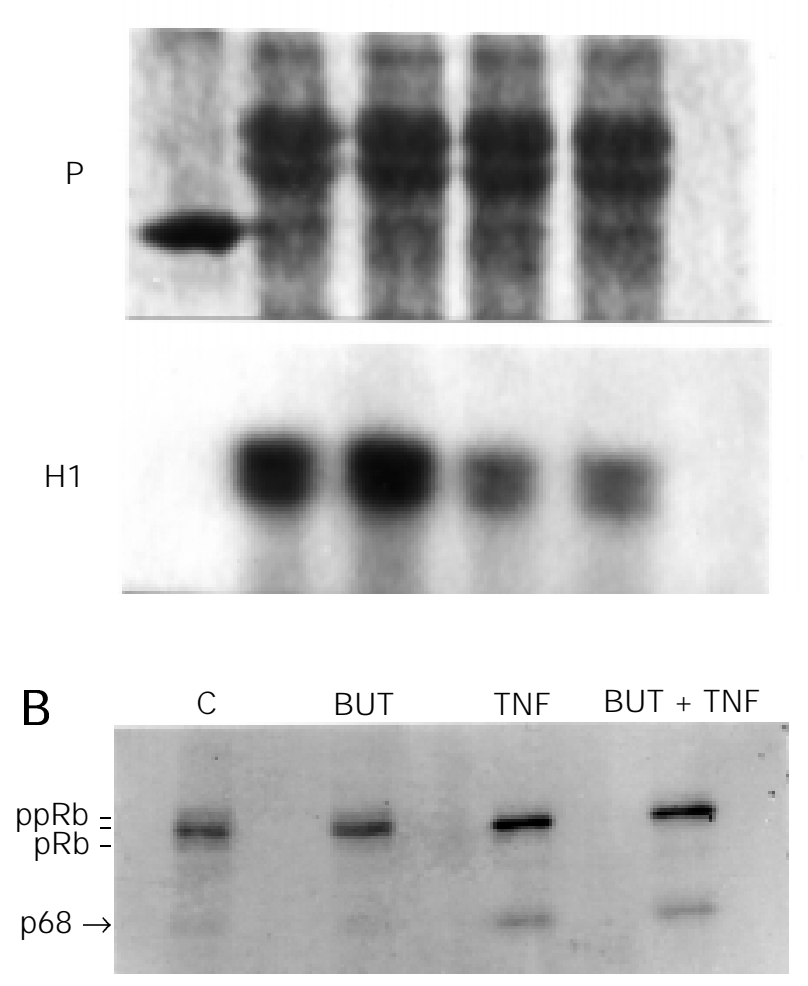

Figure 2 - A, Histone $\mathrm{H} 1$ kinase activity in the cell lysates of WEHI, L929 and HeLa cells incubated in the absence (C), in the presence of $100 \mu \mathrm{M}$ butyrolactone (BUT), tumor necrosis factor (TNF) at 1, 5 and $100 \mathrm{ng} /$ $\mathrm{ml}$, respectively, or both butyrolactone and TNF for 15 h (WEHI cells) or 24 h (L929 and HeLa cells). Equal amounts of proteins from cell lysates were incubated with $5 \mu \mathrm{g}$ histone $\mathrm{H} 1$ and $\left[\gamma_{-}{ }^{32} \mathrm{ATP}\right]$ and the level of [32P]-phosphate incorporated into histone was detected after electrophoresis on 10\% SDS/PAGE and autoradiography. Upper panel shows the pattern of protein bands (histone $\mathrm{H} 1$ and cell lysates) of Coomassiestained gels, and the lower panel shows the autoradiograph obtained with the dried stained gel after exposure to X-ray film. M, Protein molecular mass standard. $\mathrm{B}$, Phosphorylation by $\mathrm{pRb}$ kinases in the cell lysates from WEHI cells in the absence $(C)$ and in the presence of $100 \mu \mathrm{M}$ butyrolactone (BUT), TNF $(1 \mathrm{ng} / \mathrm{ml})$, and both butyrolactone and TNF after $15 \mathrm{~h}$ of incubation. Equal amounts of the cell lysate proteins were incubated with $\left[\gamma_{-32}{ }^{32} \mathrm{TP}\right]$ and the level of [32P]-phosphate incorporated into endogenous $\mathrm{pRb}$ proteins was simultaneously detected in the autoradiograph and nitrocellulose membrane containing the phosphorylated proteins after Western blotting with RB1(1F8) monoclonal antibody and the ECL detection method. The presence of a phosphoprotein of approximately $68 \mathrm{kDa}$ of molecular mass is indicated on the gel (arrow). The results are representative of three similar experiments.

\section{Discussion}

Evidence in a number of studies has suggested that oncoproteins, tumor suppressor proteins and the cell cycle regulatory proteins play a critical role in the mechanism by which normal and tumor cells respond to TNF and to pharmacological compounds that induce cell differentiation, proliferation or apoptosis $(7,8,11,17)$. Recently, several chemical inhibitors of CDKs have been found on the basis of their ability to inhibit cell cycle proliferation and/or to induce apoptosis in cancer cells $(18,19)$. The present study shows that TNF inhibits the histone $\mathrm{H} 1$ and $\mathrm{pRb}$ kinase activities associated with CDKs in the cell lines WEHI, L929 and HeLa undergoing cell cycle arrest and apoptosis, and that these biochemical effects can be sustained with butyrolactone, a specific inhibitor of protein kinases CDK-1 and CDK2. These data provide further evidence for 
the participation of CDK in the signaling pathway by which TNF induces growth arrest and apoptosis in cancer cells.

We found that butyrolactone itself does not induce apoptosis in the cell lines WEHI, L929 and HeLa used in this study, as observed for the HL-60 cell line (22). It has been shown that the general inhibitors of multiple protein kinases staurosporine and related compounds $(27,28)$, genistein and tyrphostin $(29,30)$ are potent inducers of apoptosis in some types of cancer cells. For example, staurosporine at $10 \mathrm{nM}$ concentration causes the arrest of cell cycle progression at the $\mathrm{G}_{1}$ phase which occurs concomitantly with the synthesis of the cyclin-dependent kinase inhibitors p18 and p27 and consequently the inhibition of CDK-2, CDK4 and CDK-6 activity (28). More important, apoptosis of various types of cancer cells following treatment with different cytotoxic agents frequently occurs upon the cell cycle arrest and reduction of the CDK activities associated with cyclins A, B, D and E (3135). Thus, an efficient block of the synthesis and activity of CDK/cyclin in tumor cells appears to be a crucial step toward growth arrest and apoptotic cell death. It has been reported that butyrolactone and other inhibi- tors of CDKs such as staurosporine, flavopiridol, suramin and olomoucine inhibit the CDK activity by their direct interaction with the ATP-binding site inside the CDK molecules $(18,19)$. However, we have not yet shown if $\mathrm{p} 21$, a CDK protein inhibitor transcriptionally regulated by $\mathrm{p} 53$, or its family members, p16, p18, p27 and p57, function as mediators of the TNF-induced CDK kinase suppression. The participation of the phosphatases cdc-25 (36) and retinoblastoma phosphatase (26) has also been considered because of their roles in CDK kinase activity regulation and apoptosis mediated by c-myc and $\mathrm{pRb}$ deregulation. It is important to mention that various other protein kinase families with essential roles in the cell survival pathways can also be inhibited by TNF and the competitive inhibitor for ATP binding and, therefore, contribute to the biological effects induced by these factors (37). Taken together, these data further support our hypothesis that the apoptosis process is initiated after the inhibition of multiple protein cascades which are continually activated by cell survival factors (11).

TNF-induced apoptosis is mediated by the activation of a conserved family of aspartate-specific cysteinyl proteases called

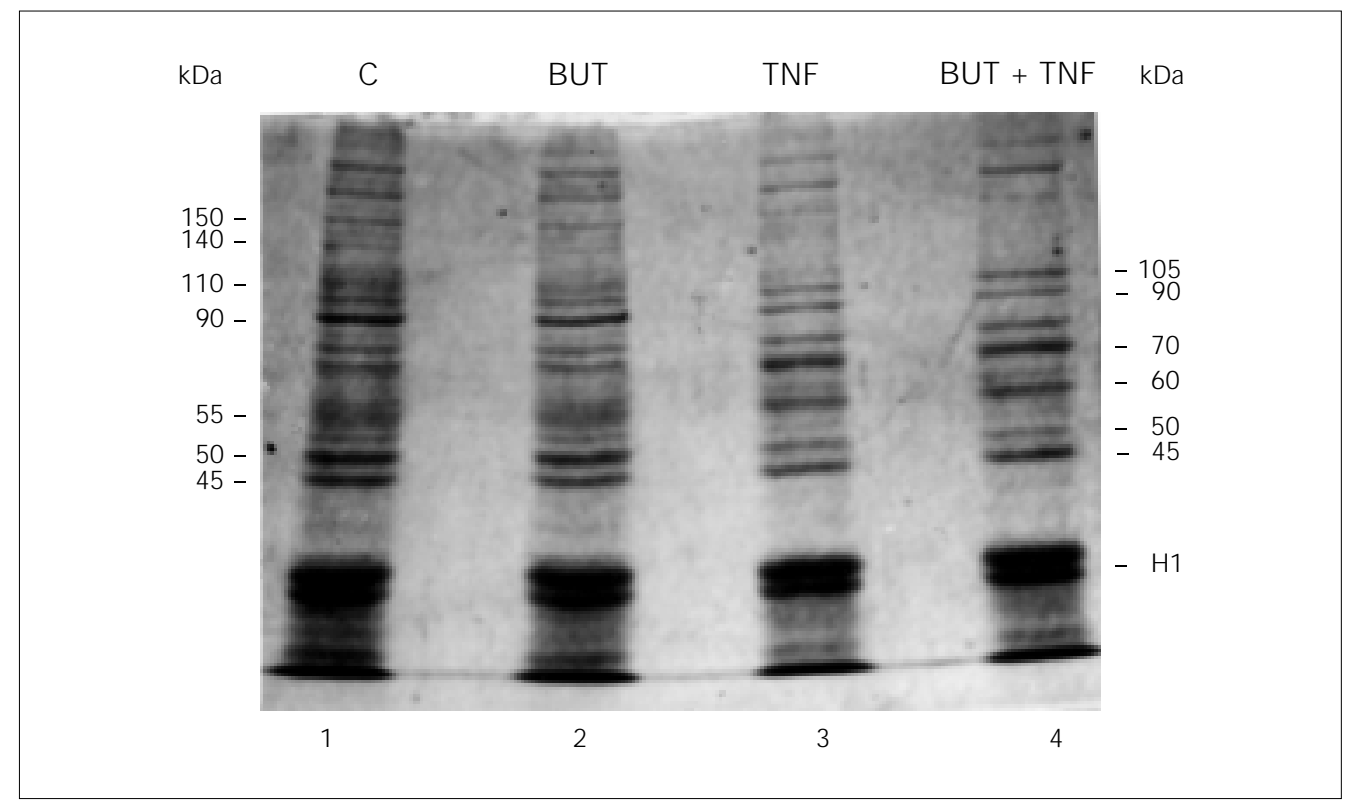

Figure 3 - Relative changes in cellular protein levels in the cell lysates from WEHI cells in the absence $(C)$ and in the presence of $100 \mu \mathrm{M}$ butyrolactone (BUT), in the presence of tumor necrosis factor (TNF) ( $1 \mathrm{ng} / \mathrm{ml})$, and of both butyrolactone and TNF after $15 \mathrm{~h}$ of incubation. Equal amounts of proteins were separated by $10 \%$ SDS/PAGE, fixed and stained with Coomassie blue. The location and the apparent molecular mass of representative protein bands are indicated on the gel. 
caspases $(21,38)$. Multiple protein substrates of caspases have been found, such as the nuclear proteins PARP, U1-70 and lamins $(5,39)$ and the cytosolic proteins gelsolin and actin $(40,41)$. In present study we have shown that either TNF or TNF plus butyrolactone provoked the loss of several cellular proteins in WEHI cells when the extent of cell death was nearly $90 \%$. We noted that the level of three major cellular protein bands of approximately 110 (pRb intermediate forms), 90 and $50 \mathrm{kDa}$ and various other weakly stained bands were markedly reduced in response to TNF. Simultaneously, we observed the appearance of new bands of 60 and 70 $\mathrm{kDa}$, supporting the idea that they may be the cleavage products of one or more proteins. These data suggest that specific modifications, including phosphorylation and proteolytic cleavage of the cellular proteins, might be involved in the molecular mechanisms behind the morphological and biochemical changes occurring during the apoptotic process. Few of the caspase-cleaved substrates are known to have direct physiological significance in apoptotic cell death. Recent studies have identified the $\mathrm{Rb}$ tumor suppressor proteins as substrates for the caspases during the apoptosis process induced by TNF and other death inducers (4244). In the present report we show that WEHI cells exposed to TNF or both TNF plus butyrolactone exclusively contain the hypophosphorylated form of $\mathrm{pRb}$ and a product of $68 \mathrm{kDa}$ (Figures 2B and 3), as reported elsewhere (44). It has been demonstrated that $\mathrm{pRb}$ functions at a checkpoint that protects cancer cells from entering the $\mathrm{S}$ phase and apoptosis in the absence of serum stimulation or deregulated expression of E2F transcription factor $(45,46)$. Therefore, we suggest a mechanism by which the cell cycledependent inactivation of CDKs by TNF and CDK chemical inhibitors and an inefficient phosphorylation of $\mathrm{Rb}$ would prime the underphosphorylated forms of $\mathrm{Rb}$ to caspases for its specific cleavage. Furthermore, the changes in the phosphorylation status and conformation structure of $\mathrm{Rb}$ proteins would allow the release of E2F, which in turn promotes $\mathrm{S}$ phase entry and induces apoptosis.

Taken together, the present findings link the decrease of cyclin-dependent kinase activity and the increase of protease activity within the growth arrest and apoptotic pathways induced by TNF. It is hoped that the identification of newer inhibitors of CDKs and the caspase substrates involved in the cell proliferation and apoptosis pathways will be of clinical importance for the therapy of many diseases.

\section{Acknowledgments}

We thank Edilene M. Lobato, Aicha M. Sarr, Amanda Machion, Branca Trindade and various members of Instituto Butantan and Universidade de São Paulo for valuable assistance and collaboration. We are also grateful to Akira Okuyama (Banyu Tsukuba Research Institute/Merck Research Labs., Okubo, Japan) and Michael A. Palladino Jr. (Genentech, South San Francisco, CA, USA) for providing butyrolactone and murine and human recombinant TNF, respectively.

\section{References}

1. Tracey KJ \& Cerami A (1993). Tumor necrosis factor, other cytokines and disease. Annual Review of Cell Biology, 9: 317343.

2. Wallach $D$, Boldin $M$, Varfolomeev $M$, Beyaert R, Vandenabeele $P$ \& Fiers W (1997). Cell death induction by receptors of the TNF family: towards a molecular understanding. FEBS Letters, 410: 96106.

3. Thompson CB (1995). Apoptosis in the pathogenesis and treatment of disease. Science, 267: 1458-1462.

4. Vaux DL \& Strasser A (1996). The molecu- lar biology of apoptosis. Proceedings of the National Academy of Sciences, USA, 93: 2239-2244.

5. Miller (1997). The role of the caspase family proteases in apoptosis. Seminars in Immunology, 9: 35-49.

6. Hawkins CJ \& Vaux D (1997). The role of 
the Bcl-2 family of apoptosis regulatory proteins in the immune system. Seminars in Immunology, 9: 25-33.

7. Sherr CJ (1996). Cancer cell cycle. Science, 274: 1672-1677.

8. Hunter T (1997). Oncoprotein network. Cell, 88: 333-346.

9. Evan GL, Brown L, Whyte $M \&$ Harrington E (1995). Apoptosis and the cell cycle. Current Opinnion in Cell Biology, 7: 825-834.

10. Belizario J E \& Dinarello CA (1991). Interleukin-1, interleukin-6, tumor necrosis factor- $\alpha$ and transforming growth factor- $\beta$ increase cell resistance to TNF cytotoxicity by growth arrest in the $G_{1}$ phase of the cell cycle. Cancer Research, 51: 23792385.

11. Belizário J E, Sherwood SW \& Beçak W (1999). Inhibition of multiple protein kinase cascades in cell undergoing cell cycle arrest and apoptosis in response to TNF. Cancer Research (in press).

12. J eoung D, Tang B \& Sonenberg M (1995). Effects of TNF- $\alpha$ on anti-mitogenicity and cell cycle-related proteins in MCF-7 cells. J ournal of Biological Chemistry, 270: 18367-18373.

13. Vieira KBL, Goldstein DJ \& Villa LL (1996). Tumor necrosis factor- $\alpha$ interferes with the cell cycle of normal and papillomavirus-immortalized human keratinocytes. Cancer Research, 56: 2452-2457.

14. Yin D, Kondo S, Barnett GH, Morimura T \& Takeuchi J (1995). Tumor necrosis factor- $\alpha$ induce p53-dependent apoptosis in rat glioma cells. Neurosurgery, 37: 758762.

15. J acobsen FW, Dubois CM, Rusten LS, Veiby OP \& J acobsen SE (1995). Inhibition of stem cell factor-induced proliferation of primitive murine hematopoietic progenitor cells signalling through the 75kDa TNFR. J ournal of Immunology, 154: 3732-3741.

16. Shiohara M, Akashi M, Gombart AF, Yang R \& Koeffler HP (1996). Tumor necrosis factor- $\alpha$ : posttranscriptional stabilization of WAF1 mRNA in p53-deficient human leukemic cells. J oumal of Cellular Physiology, 166: 568-576.

17. J anicke RU, Lin XY \& Porter AG (1996). Cyclin D3 sensitizes tumor cells to TNFinduced c-myc dependent apoptosis. Molecular and Cellular Biology, 16: 52455253.

18. Meijer L (1996). Chemical inhibitors of cyclin-dependent kinases. Trends in Cell Biology, 6: 393-397.

19. Meijer L \& Kim S-H (1997). Chemical inhibitors of cyclin-dependent kinases. Methods in Enzymology, 283: 113-128.
20. Kitagawa $M$, Okabe $T$, Ogino $H$, Matsumoto H, Takahashi IS, Kokubo T, Higashi $\mathrm{H}$, Saitoh S, Taya Y, Yasuda $\mathrm{H}$, Ohba Y, Nishimura S, Tanaka N \& Okuyama A (1993). Butyrolactone I, a selective inhibitor of cdk2 and cdc2 kinase. Oncogene, 8: 2425-2432.

21. Kitagawa M, Higashi H, Takahashi IS, Okabe T, Ogino H, Taya Y, Nishimura S \& Okuyama A (1994). A cyclin-dependent kinase inhibitor, butyrolactone I, inhibits phosphorylation of RB protein and cell cycle progression. Oncogene, 9: 25492557.

22. Shibata $Y$, Nishimura S, Okuyama A \& Nakamura T (1996). p53-independent induction of apoptosis by cyclin-dependent kinase inhibition. Cell Growth and Differentiation, 7: 887-891.

23. Belizario J E, Tilly J \& Sherwood SW (1993). Caffeine potentiates the lethality of tumor necrosis factor in cancer cells. British J ournal of Cancer, 67: 1229-1235.

24. Simanis V\& Nurse $P(1986)$. The cell cycle control gene $\mathrm{cdc} 2+$ of fission yeast encodes a protein kinase potentially regulated by phosphorylation. Cell, 45: 261268.

25. Laemmli UK (1970). Cleavage of structural proteins during assembly of the head of bacteriophage T4. Nature, 227: 22-27.

26. Dou QP, An B \& Will PL (1995). Induction of a retinoblastoma phosphatase activity by anticancer drugs accompanies p53-independent $\mathrm{G}_{1}$ arrest and apoptosis. Proceedings of the National Academy of Sciences, USA, 92: 9019-9023.

27. Wang Q, Worland PJ, Clark J L, Carlson BA \& Sausville EA (1995). Apoptosis in 7hydroxystauropurine-treated T lymphoblasts correlates with activation of cyclindependent kinases 1 and 2. Cell Growth and Differentiation, 6: 927-936.

28. Kwon TK, Buchholz MA, Chrest FJ \& Nordin AA (1996). Staurosporine-induced $\mathrm{G}_{1}$ arrest is associated with the induction and accumulation of cyclin-dependent kinase inhibitors. Cell Growth and Differentiation, 7: 1305-1313.

29. Tallett A, Chilvers ER, Hannah S, Dransfield I, Lawson MF, Haslett C \& Sethi T (1996). Inhibition of neuropeptidestimulated tyrosine phosphorylation and tyrosine kinase activity stimulates apoptosis in small cell lung cancer cells. Cancer Research, 56: 4255-4263.

30. Gjertsen BT \& Doskeland SO (1995). Protein phosphorylation in apoptosis. Biochemica et Biophysica Acta, 1269: 187-199.

31. Lock RB (1992). Inhibition of p34/cdc-2 kinase activation, p34/cdc-2 tyrosine de- phosphorylation, and mitotic progression in Chinese hamster ovary cells exposed to etoposide. Cancer Research, 52: 18171822.

32. Dulic V, Kaufmann WK, Wilson SJ, Tisty TD, Lees E, Harper JW, Elledge SJ \& Reed SI (1994). p53-dependent inhibition of cyclin-dependent kinase activities in human fibroblasts during radiation-induced $\mathrm{G}_{1}$ arrest. Cell, 76: 1013-1023.

33. Norbury $C$, MacFarlane $M$, Fearnhead $\mathrm{H} \&$ Cohen GM (1994). CDC2 activation is not required for thymocyte apoptosis. Biochemical and Biophysical Research Communications, 202: 1400-1406.

34. Oberhammer FA, Hochegger K, Froschl G, Tiefenbacher R \& Pavelka M (1994). Chromatin condensation during apoptosis is accompanied by degradation of lamin A + B, without enhanced activation of cdc2 kinase. J ournal of Cell Biology, 126: 827-837.

35. Neamati N, Fernandez A, Wright S, Kiefer J \& McConkey DJ (1995). Degradation of lamin B1 precedes oligonucleosomal DNA fragmentation in apoptotic thymocytes and isolated thymocyte nuclei. J ournal of Immunology, 154: 3788-3795.

36. Galaktionov K, Chen X \& Beach D (1996). Cdc- 25 cell cycle phosphatase as a target of c-myc. Nature, 38: 511-517.

37. Amarante-Mendes GP \& Green DR (1997). Abl tyrosine kinase and the control of apoptosis. In: Martin SJ (Editor), Apoptosis and Cancer. R.G. Landes Company, Austin, TX.

38. Boldin MP, Goncharov TM, Goltsev YV \& Wallach D (1996). Involvement of MACH, a novel MORT1/FADD-interacting protease in Fas/APO-1 and TNF receptor-induced cell death. Cell, 85: 803-815.

39. Casciola-Rosen LA, Miller DK, Anhalt GJ $\&$ Rosen A (1994). Specific cleavage of the $70-\mathrm{kDa}$ protein component of U1 small nuclear ribonucleoprotein is a characteristic biochemical feature of apoptotic cell death. J ournal of Biological Chemistry, 269: 30757-30760.

40. Kayalar C, Ord T, Testa MP, Zhong L-T \& Bredesen DE (1996). Cleavage of actin by interleukin $1 ß$-converting enzyme to reverse DNA I inhibition. Proceedings of the National Academy of Sciences, USA, 93: 2234-2238.

41. Kothakota S, Azuma T, Reinhard C, Klippel A, Tang J , Chu K, McGarry TJ , Kirschner MW, Koths K, Kwiatkowski DJ \& Williams LT (1997). Caspase-3-generated fragment of gelsolin: effector of morphological change in apoptosis. Science, 278: 294298. 
42. J anicke RU, Walker PA, Yu X \& Porter AG (1996). Specific cleavage of the retinoblastoma protein by an ICE-like protease in apoptosis. EMBO J oumal, 15: 69696978.

43. Tan X, Martin SJ, Green DR \& Wang J Y J (1997). Degradation of retinoblastoma protein in tumor necrosis factor- and CD95-induced cell death. J ournal of Bio- logical Chemistry, 272: 9613-9616.

44. An B \& Dou QP (1996). Cleavage of retinoblastoma protein during apoptosis: an interleukin $1 ß$-converting enzyme-like protease as candidate. Cancer Research, 56: 438-442.

45. Haas-Kogan DA, Kogan SC, Levi D, Dazin $P, T^{\prime}$ Ang $T$, Fung $Y-K$, Fung $T \&$ Israel MA (1995). Inhibition of apoptosis by the reti- noblastoma gene product. EMBO J ournal, 14: 461-472.

46. Shan B, Durfee T \& Lee W-H (1966). Disruption of RB/E2F-1 interaction by single point mutations in E2F-1 enchances Sphase entry and apoptosis. Proceedings of the National Academy of Sciences, USA, 93: 679-684. 